\title{
LIVING POSITIVE EXPERIENCES IN STORE: HOW IT INFLUENCES SHOPPING EXPERIENCE VALUE AND SATISFACTION?
}

\author{
Silvia CACHERO-MARTÍNEZ ${ }^{1}$, Rodolfo VÁZQUEZ-CASIELLES ${ }^{2}$ \\ ${ }^{1}$ Facultad de Economía y Empresa, Universidad de Oviedo, Cátedra Fundación Ramón Areces \\ de Distribución Comercial, Avenida del Cristo, s/n, 33071 Oviedo (Asturias), Spain \\ ${ }^{2}$ Facultad de Economía y Empresa, Universidad de Oviedo, Avenida del Cristo, \\ $s / n, 33071$ Oviedo (Asturias), Spain \\ E-mails: ${ }^{1}$ cacherosilvia@uniovi.es (correspondingauthor); ${ }^{2}$ rvazquez@uniovi.es
}

Received 2015 November 30; accepted 18 December 2016

\begin{abstract}
Retailers have tried to differentiate themselves from their competitors through shopping experience. This is the first study analysing relationships between experience dimensions, shopping experience value and satisfaction. In this article different shopping experience dimensions are identified: emotional, sensory, intellectual, social, and pragmatic. In-depth interviews were conducted with a panel of experts to adapt a set of experience dimensions identified from the literature to the offline environment. A survey was then designed to collect data from consumers who had bought in a retailer, where marketing strategies are linked with experience dimensions. Retailers may use this typology in order to re-design their marketing strategies. Retailers must invest in utilitarian attributes of product assortment offered to consumers, improving quality while maintaining prices and promotions. If a retailer can stimulate social shopping and consumer curiosity, such as imagination and creativity in the store, they will have more devoted consumers.
\end{abstract}

Keywords: experience marketing, emotion, value, satisfaction, consumer behaviour, retailing.

JEL Classification: M31.

\section{Introduction}

One of the first academic papers to analyse the concept of experience is that of Holbrook and Hirschman (1982). These authors suggest that a traditional information-processing approach by the consumer (focusing on product attributes) should not exclude experiences involving consumer's imagination and emotions.

From this perspective, in recent years retail companies have been interested in positive experience development in stores. Our initial assumption is that customer's surprise, resulting from their active participation in a store, can cause different emotions (e.g. happy and entertaining). 
Although there are several studies on consumer experience (Gentile et al. 2007; Brakus et al. 2009; Schmitt 2010; Schmitt et al. 2015; Verleye 2015; Bhandari 2016), in most cases they refer to brand experiences, not to experiences in a retailer. This paper presents a helpful decision-making process for retailers who are interested in the experience economy. Academically, the originality of the paper is that the model is in line with Stimulus-Organism-Response (SOR) theory, applied to shopping experiences.

The aim of this paper is twofold. On one hand, the study identifies different dimensions of consumer experience in a retailer. On the other hand, this research resolves a gap in our knowledge with an analysis of relationships between experience dimensions, shopping experience value and satisfaction.

\section{Theoretical framework and hypothesis development}

Mehrabian and Russell (1974) propose the SOR model, which indicates that the external physical environment can influence an individual's internal state and behaviours. The theoretical framework of this study (Figure 1) is developed based on the adaptation of the SOR to customer experience. In a retailer the stimulus integrates different dimensions of consumer experience: sensory, intellectual, social and pragmatic. The organism is defined by the affective state of the consumer, covering emotional experience. The response includes two experience value dimensions and satisfaction.

Marketing literature has identified different consumer experience dimensions. Table 1 presents the most relevant researches.

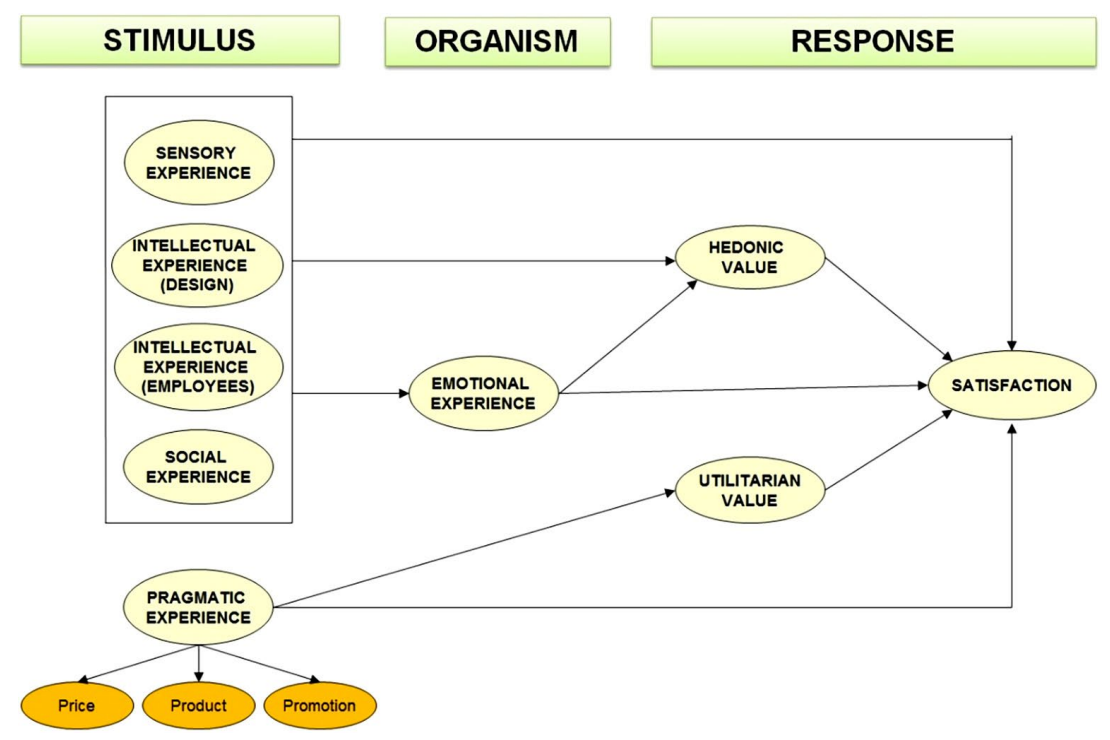

Fig. 1. Conceptual model 
Table 1. Customer experience dimensions

\begin{tabular}{|c|c|}
\hline Authors & Main focus \\
\hline $\begin{array}{l}\text { O’Sullivan and } \\
\text { Spangler (1998) }\end{array}$ & $\begin{array}{l}\text { Five dimensions of experience quality: physical surroundings, service providers, } \\
\text { other customers, customers' companions, and customers themselves. }\end{array}$ \\
\hline $\begin{array}{l}\text { Pine and } \\
\text { Gilmore } \\
(1998 ; 1999)\end{array}$ & $\begin{array}{l}\text { Their approach consists of four realms given by people's participation } \\
\text { and people's connection or environmental relationship in the experience: } \\
\text { entertainment, education, esthetics and escapism. }\end{array}$ \\
\hline $\begin{array}{l}\text { Schmitt (1999) } \\
\text { Schmitt (2003) }\end{array}$ & $\begin{array}{l}\text { Five dimensions of experience: sensorial; affective; creative cognitive; physical, } \\
\text { behaviors and lifestyle and social-identity. }\end{array}$ \\
\hline $\begin{array}{l}\text { Dubé y LeBel } \\
(2003)\end{array}$ & $\begin{array}{l}\text { Four "pleasure dimensions": emotional, intellectual, physical and social } \\
\text { pleasures. }\end{array}$ \\
\hline $\begin{array}{l}\text { Gentile et al. } \\
\text { (2007) }\end{array}$ & $\begin{array}{l}\text { Six dimensions of experience: sensorial, emotional, cognitive, pragmatic, } \\
\text { lifestyle and relational. }\end{array}$ \\
\hline $\begin{array}{l}\text { Brakus et al. } \\
\text { (2009) }\end{array}$ & $\begin{array}{l}\text { Five dimensions of brand experience: sensorial, affective, behavioral and } \\
\text { intellectual. }\end{array}$ \\
\hline $\begin{array}{l}\text { Verhoef et al. } \\
\text { (2009) }\end{array}$ & $\begin{array}{l}\text { They build a conceptual model of antecedents of customer experience. They } \\
\text { identify four dimensions of experience: cognitive, affective, social and physical. }\end{array}$ \\
\hline Schmitt (2010) & $\begin{array}{l}\text { Two dimensions of experience: ordinary (occur as part of everyday life) and } \\
\text { extraordinary (more active, intense and stylized). }\end{array}$ \\
\hline
\end{tabular}

\subsection{Emotional experience}

An important dimension of experience construction is the emotions (e.g. happiness, enjoyment). Consumers buy goods and services as a means to fulfil deeper emotional experiences and hedonic aspirations. Therefore, marketing literature advocates greater attention to hedonic consumption (Alba, Williams 2013).

Emotions arising from shopping experiences deposit affective memory traces, which consumers process and integrate to form post-shopping satisfaction (Ali et al. 2016). Thus:

H1: Emotional experience has a positive influence on satisfaction.

\subsection{Antecedents of emotional experience}

In the following sub-sections we discuss sensory experience, as well as other determinants of emotional experience that are less intuitive than those that are purely sensory.

\subsubsection{Sensory experience}

Sensory marketing is defined as "marketing that engages the consumer's senses and affects their perceptions, judgments and behaviours" (Krishna 2013: 5-6). Research on retail atmosphere has focused on experiences that customers detect by the senses of touch, smell, audition, vision and taste (Möller, Herm 2013).

\section{Tactile experience}

In developing taxonomy of touch in consumer behaviour two types of touch are evident (Peck 2010): instrumental and hedonic. The first type assumes that the consumer is en- 
gaged in touch as a means to an end. The second type is the hedonic touch, where touch is an end by itself. Hedonic touch may generate emotional experience and satisfaction (George 2015).

\section{Scent experience}

Scent marketing is defined as using scents to set a mood, promote products or position a brand (Morrin 2010). Retailers emit scents as an element of the environment to create positive emotions and satisfaction (Rimkute et al. 2016).

\section{Auditory experience}

Retailers have used music intentionally to enhance shopping experience (Lang 2015). The research focuses on three dimensions: tempo, type and volume (Krishna 2010, 2013). Music tempo is often correlated with emotional experience (e.g. slow tempo relaxes consumers and fast tempo creates states of auditory arousal in its listeners). Different music types can also be a cross-promotional tool that can link stores with similar target customers and strengthen satisfaction. Third, music volume also influences the time customers spend in stores and their satisfaction.

\section{Visual experience}

The effect of visual cues on customer judgment is via three different constructs (Raghubir 2010): attention, imagery and neural activation. These constructs influence the conscious or unconscious information processed by the customer and generate a variety of responses, including emotions and satisfaction (Labrecque, Milne 2011; Sachdeva, Goel 2015).

\section{Taste Experience}

Rather than being a sense in itself, taste is understood as a mix of all our senses. Cues based on our senses of hearing, sight, touch, and especially scent can affect our perceptions of taste (Krishna 2013; Lawton 2016).

\section{Multi-sensory experience}

Some academics have begun to pay attention to interplay between the senses. For example, inter-sensory effects between vision and taste (Hoegg, Alba 2007), touch and taste (Krishna, Morris 2008) and vision and touch (Krishna 2006, 2010).

In summary, marketing stimulus associated with sensory experience, is not only a source of satisfaction but also allows consumers to experience emotions (Bagozzi et al. 1999). Hence:

H2a: Favourable perceptions of sensory experience have a positive influence on emotional experience.

H3a: Favourable perceptions of sensory experience have a positive influence on satisfaction.

\subsubsection{Intellectual experience}

Intellectual experiences happen when the retailer's merchandising strategy (intellectual experience through design) and/or interaction with employees (intellectual experience with employees) help to stimulate customer curiosity and invite them to think. Some 
academics affirm that curiosity produces positive outcomes for retailer (Hill et al. 2016). An emerging tool for marketers is augmented reality (Scholz, Smith 2016; Javornik 2016).

Intellectual experience is more likely to be social and to be discussed with others (e.g. employees), both of which can increase satisfaction and the enjoyment of positive experiences (Foroudi et al. 2016). Therefore:

H2b: Favourable perceptions of intellectual experience (through design and employees) have a positive influence on emotional experience.

H3b: Favourable perceptions of intellectual experience (through design and employees) have a positive influence on satisfaction.

\subsubsection{Social experience}

Social experience involves the person and his/her social context, his/her relationship with other people and with his/her ideal self (Ferguson et al. 2010). For example, go shopping with family/friends and get information about new products; interact with other customers; go to a shop as a means of affirmation of a social identity.

The relationship with other customers facilitates the development of several types of social influence that can generate satisfaction (Mangleburg et al. 2004). Furthermore, it can result in positive emotions (Gentile et al. 2007; Smillie et al. 2015). Hence:

H2c: Favourable perceptions of social experience have a positive influence on emotional experience.

H3c: Favourable perceptions of social experience have a positive influence on satisfaction.

\subsection{Pragmatic experience}

Pragmatic experience is mainly based on the utilitarian activity of the retailer; in so much as it tries to satisfy a customer motivated by monetary value and utility of products, and not by their aesthetic or design. Sometimes the customer can also experience emotions derived from pragmatic experience (Spinelli et al. 2015). Customers consider the seemingly utilitarian activity of price/promotion shopping, which can be pleasurable for a variety of non-monetary reasons, including the hedonic benefits provided by non-monetary promotions, or even the simple emotion of getting a good deal (Alba, Williams 2013). However, our study only considered that pragmatic experience is related to utilitarian purchases, where consumers wish to get the most useful product for its price (Walsh et al. 2011). In summary:

H3d: Favourable perceptions of pragmatic experience have a positive influence on satisfaction.

\subsection{Value perception towards shopping experience}

Different studies (Babin et al. 1994; Mathwick et al. 2001; Fiore, Kim, 2007; Kim et al. 2007, 2014; İpek et al. 2016) used various dimensions of shopping experience and perceived value. Babin et al. (1994) proposed two experience value dimensions: 
hedonic and utilitarian. Hedonic value is related to enjoyment and playfulness, reflecting the experiential side of shopping, comprising pleasure and curiosity (Scarpi et al. 2014). The main antecedent of hedonic value is the emotional experience (Jackson et al. 2011). The utilitarian customer wants a cognitive experience, which includes prices, promotions and that the act of acquisition may be attained with minimal effort. The main antecedent of utilitarian value is pragmatic experience. Accordingly:

H4: Emotional experience has a positive influence on hedonic value.

H5: Pragmatic experience has a positive influence on utilitarian value.

Both hedonic and utilitarian value, allow the retailer to obtain satisfaction (Arnold, Reynolds 2009, 2012; Gholami et al. 2016). Thus:

H6: Favourable perceptions of (a) hedonic value and (b) utilitarian value have a positive influence on satisfaction.

\section{Methodology}

\subsection{Sample and a questionnaire}

For the generation of items and experience dimensions, five sources of data were used. First, we review experience and emotions literature (Schmitt 2003; Gentile et al. 2007; Brakus et al. 2009) and hedonic consumption. Second, we visit stores from different sectors. Third, through a focus group interview, consumers were asked to write any pleasant experience they had had in a retailer.

Fourth, in-depth interviews were conducted with ten customers and a panel of experts. This panel performed four tasks: (1) assessed the similarity of items, the clarity of phrasing and the terminology used in the scale, (2) rated the importance of each item in the determination of the experience dimensions, (3) suggested if it is necessary to add some item to each experience dimensions, and (4) indicated whether it was relevant to add some new experience dimension. The main conclusion is that the experts consider it appropriate to divide intellectual experience into two dimensions: one through design and the other through employees. Furthermore, we proceeded to reduce the number of items, rewording and assigning items to experience dimensions. Thus, the resulting purified scale comprises six experience dimensions with 36 corresponding items.

Finally, we performed a pre-test of measurement scales on experience dimensions. Personal interviews were conducted to a sample of thirty retailer-loyal consumers with experience in marketing strategies. The results allowed us to understand the function of measurement scales, modifying wording to facilitate interpretation. The result of the identification of experiences is the measurement scale shown in Table 2.

Later was made a field survey. The format of the scales was: emotional experience is measured as the intensity of emotions, with responses ranging from " 1 - Not at All" to "7 - Completely", and the rest of the measures were in a Likert scale, with responses ranging from "1 - Strongly Disagree" to "7 - Strongly Agree". Existing measurements were used: Babin et al. (1994) and Jones et al. (2006) for experience value and Oliver (2010) for satisfaction. 
Table 2. Measurement model (reliability and validity)

Consumer experience dimensions (and other constructs)

Standardized

Factor Loading

Sensory experience $(\mathrm{A}=0.891 ; \mathrm{CR}=0.886 ; \mathrm{AVE}=0.569)$

$\mathrm{I} 1$ = Temperature is suitable, activating shopping experience

0.657

I 2 = Cleanliness and good condition stimulates shopping experience

0.804

I3 = Lighting is motivating, making shopping experience pleasant

0.858

I4 $=$ Color of walls and floor provide a shopping experience in a pleasant

0.863 environment

I5 = Music (tempo, volume and type) provides a very pleasant shopping $\quad 0.660$ experience

I6 $=$ Smells provides a very pleasant shopping experience

0.648

Intellectual experience (design) $(\mathrm{A}=0.903 ; \mathrm{CR}=0.897 ; \mathrm{AVE}=0.557)$

I7 = Design (furniture and decor) stimulates curiosity 0.801

I8 = Sections design stimulates shopping experience and interacting 0.788

with the product

I9 = Communication materials (display) stimulates imagination and creativity

0.774

consumer

$\mathrm{I} 10=$ Store layout stimulates curiosity

0.834

I11 = Shop-window offers an attractive presentation (artistic, creative)

0.672

$\mathrm{I} 12=$ Store has a pleasant entry (spacious and inviting)

0.683

I13 = Outside of store design invites you to enter

0.653

Intellectual experience (employees) $(\mathrm{A}=0.869 ; \mathrm{CR}=0.860 ; \mathrm{AVE}=0.614)$

I14 $=$ Employees are always willing to help (provide information, support to decision-making) and answer all customer questions

I15 = Employees have great knowledge of what they sell and the experiences that the products provide

I16 $=$ There are enough employees to offer personalized service and explain

the experiences provided by the use of products

I17 = Payment for items purchased is fast avoiding negative experiences

0.558

Social experience $(\mathrm{A}=0.797 ; \mathrm{CR}=0.808 ; \mathrm{AVE}=0.587)$

I18 = Shopping at this store give me the opportunity to experience feeling of status (interact with other customers)

I19 $=$ Shopping at this store allows me to get information and experiences on trends consistent with my lifestyles

$\mathrm{I} 20=$ Go to this store allows me to spend a pleasant time with my family/friends $\quad 0.666$

Pragmatic experience (price) $(\mathrm{A}=0.856 ; \mathrm{CR}=0.859 ; \mathrm{AVE}=0.620)$

$\begin{array}{ll}\mathrm{I} 21=\text { In this store I get quality products at a good price } & 0.788\end{array}$

I22 = Compared with other competitors this store offers the best price-quality $\quad 0.847$ 
End of Table 2

Consumer experience dimensions (and other constructs)

Standardized

Factor Loading

I23 = This store offers a variety of services (warranty, product returns,

0.819 home delivery) with good prices

Pragmatic experience (product) $(\mathrm{A}=0.711 ; \mathrm{CR}=0.756 ; \mathrm{AVE}=0.509)$

\begin{tabular}{ll}
\hline I24 = Brands offered are known and good quality & 0.686 \\
\hline I25 = Product assortment is sufficient to meet my needs & 0.731 \\
\hline I26 = Periodically updates its assortment incorporating the latest product version & 0.722 \\
\hline
\end{tabular}

Pragmatic experience (promotions) $(\mathrm{A}=0.824 ; \mathrm{CR}=0.828 ; \mathrm{AVE}=0.548)$

\begin{tabular}{ll}
\hline I27 $=$ It offers better promotions than competition & 0.758 \\
\hline I28 = Consumer information about promotions is very suitable & 0.822 \\
\hline I29 = Always have stock of products on promotion & 0.723 \\
\hline I30 = In promotional periods product quality is maintained & 0.648
\end{tabular}

Emotional experience (intensity of emotions) $(\mathrm{A}=0.945 ; \mathrm{CR}=0.940 ; \mathrm{AVE}=0.724)$

\begin{tabular}{ll}
\hline Happy (joyful) & 0.890 \\
\hline Hopeful & 0.881 \\
\hline Entertaining & 0.841 \\
\hline Animated (encouraged) & 0.847 \\
\hline Enthusiastic & 0.973 \\
\hline Surprised & 0.768
\end{tabular}

Hedonic value $(\mathrm{A}=0.891 ; \mathrm{CR}=0.872 ; \mathrm{AVE}=0.696)$

I enjoyed this shopping trip for its own sake, not just for the products I may have $\quad 0.902$ purchased

\begin{tabular}{ll}
\hline I continued to shop, not because I had to, but because I wanted & 0.773
\end{tabular}

Compared to other things I could have done, time spent in this store was truly $\quad 0.822$ enjoyable

Utilitarian value $(\mathrm{A}=0.776 ; \mathrm{CR}=0.798 ; \mathrm{AVE}=0.574)$

I accomplished just what I wanted to on this shopping trip

0.882

I was disappointed because I had to go to another store to complete

0.592 my shopping $(\mathrm{R})$

I feel this shopping trip was successful (I found the product very quickly)

0.771

Satisfaction $(\mathrm{A}=0.887 ; \mathrm{CR}=0.887$; $\mathrm{AVE}=0.664)$

I'm satisfied; this is one of the best stores I have visited

0.754

I'm satisfied with the products/services of this store

0.841

I'm satisfied because I enjoyed the shopping experience in the store

0.855

I don't regret for choosing this store to make the purchase

0.805

Note: $\mathrm{A}=$ Cronbach's Alpha; $\mathrm{CR}=$ Composite Reliability; AVE = Average Variance Extracted; $\mathrm{R}=$ Item reverse; $\mathrm{I}=$ number of item. 
Information was collected using personal surveys on the street and online surveys. These surveys were made from March to November 2015, when consumers step out the store or inviting consumers to think about the last purchase they made.

The sample consisted of 527 people from several cities in Spain. The sample distribution was done by levels of age (65\% between 18 and 44 years and 35\% over 45 years) and gender $(57 \%$ female). The sample distribution by sectors is: clothing stores and fashion (44\%); shoes (7.2\%); cosmetics and perfumery (9\%); jewellery $(3.4 \%)$; sports $(9.3 \%)$; electronics $(8.7 \%)$; decoration $(6.6 \%)$; bookstores $(9.1 \%)$ and toys $(2.7 \%)$. These sectors have been selected because retailers offer hedonic and utilitarian experiences and develop marketing activities providing people with emotional and pragmatic experiences.

\subsection{Scales purification of experience dimensions, experience value and satisfaction}

To analyse the data structure, we performed an exploratory factor analysis (EFA). This revealed five factors that explained $68.2 \%$ of the variance (Tables 3 and 4). Because we did anticipate that pragmatic experience items would load on a second-order factors, we conducted another exploratory factor analysis on the 10 pragmatic items. After Varimax rotation, analysis revealed three factors (product, price and promotion) which explained $69.7 \%$ of the variance.

Table 3. EFA: consumer experience dimensions

\begin{tabular}{|c|c|c|c|c|c|}
\hline ITEM & Sensory & Intellectual (design) & Intellectual (employees) & Social & Variance explained \\
\hline I1 & 0.780 & 0.145 & 0.165 & 0.024 & \multirow{6}{*}{$19.364 \%$} \\
\hline $\mathrm{I} 2$ & 0.799 & 0.304 & 0.168 & 0.056 & \\
\hline $\mathrm{I} 3$ & 0.768 & 0.357 & 0.135 & 0.108 & \\
\hline I4 & 0.738 & 0.405 & 0.083 & 0.173 & \\
\hline I5 & 0.612 & 0.250 & 0.036 & 0.436 & \\
\hline I6 & 0.586 & 0.241 & 0.068 & 0.468 & \\
\hline I7 & 0.500 & 0.619 & 0.104 & 0.161 & \multirow{7}{*}{$20.786 \%$} \\
\hline I8 & 0.326 & 0.729 & 0.261 & -0.001 & \\
\hline I9 & 0.250 & 0.745 & 0.208 & 0.114 & \\
\hline $\mathrm{I} 10$ & 0.270 & 0.788 & 0.121 & 0.209 & \\
\hline I11 & 0.206 & 0.651 & 0.144 & 0.350 & \\
\hline $\mathrm{I} 12$ & 0.304 & 0.663 & 0.056 & 0.262 & \\
\hline $\mathrm{I} 13$ & 0.196 & 0.636 & 0.068 & 0.454 & \\
\hline $\mathrm{I} 14$ & 0.125 & 0.166 & 0.849 & 0.078 & \multirow{4}{*}{$16.707 \%$} \\
\hline $\mathrm{I} 15$ & 0.075 & 0.129 & 0.861 & 0.114 & \\
\hline I16 & 0.091 & 0.056 & 0.816 & 0.201 & \\
\hline $\mathrm{I} 17$ & 0.129 & 0.113 & 0.724 & 0.070 & \\
\hline $\mathrm{I} 18$ & 0.127 & 0.257 & 0.496 & 0.545 & \multirow{3}{*}{$11.343 \%$} \\
\hline I19 & 0.186 & 0.332 & 0.317 & 0.667 & \\
\hline I20 & 0.103 & 0.192 & 0.194 & 0.761 & \\
\hline
\end{tabular}


Table 4. EFA: pragmatic experience

\begin{tabular}{|c|c|c|c|c|}
\hline ITEM & Price & Product & Promotion & Variance explained \\
\hline $\mathrm{I} 21$ & 0.777 & 0.300 & 0.210 & \multirow{3}{*}{$25.643 \%$} \\
\hline $\mathrm{I} 22$ & 0.883 & 0.115 & 0.233 & \\
\hline $\mathrm{I} 23$ & 0.782 & 0.290 & 0.240 & \\
\hline $\mathrm{I} 24$ & 0.215 & 0.724 & 0.112 & \multirow{3}{*}{$23.317 \%$} \\
\hline $\mathrm{I} 25$ & 0.175 & 0.744 & 0.196 & \\
\hline $\mathrm{I} 26$ & 0.152 & 0.804 & 0.144 & \\
\hline I27 & 0.394 & -0.016 & 0.745 & \multirow{4}{*}{$20.716 \%$} \\
\hline $\mathrm{I} 28$ & 0.156 & 0.114 & 0.864 & \\
\hline $\mathrm{I} 29$ & 0.116 & 0.256 & 0.778 & \\
\hline $\mathrm{I} 30$ & 0.210 & 0.282 & 0.656 & \\
\hline
\end{tabular}

\subsection{Statistical analysis}

CFA was applied to assess validity and reliability of the model (Fig. 1) (Wang, Ahmed 2004). EQS 6.2 was employed to conduct CFA. The fit measures suggested a reasonable fit: $\mathrm{GFI}=0.845 ; \mathrm{CFI}=0.939$ (greater than 0.9 proposed by Hair et al. 2006); $\mathrm{BBNNFI}=0.923$; RMSEA $=0.039$ (lower than 0.08 recommended by $\mathrm{Hu}$ and Bentler 1999); SRMR =0.055; all indicating acceptable fit. In addition, the ratio between the chi-square statistic and the number of degrees of freedom was 1.815 , indicating an adequate fit (Thomson et al. 2005). All indicators were significant $(p<0.001)$ and substantial (standardised factor loadings 0.6 or above) (Hair et al. 2006) on their theoretical constructs. Cronbach's alpha coefficient was greater than 0.7 (Nunnally 1978), the composite reliability was greater than 0.7 and the AVE was greater than 0.5 (Table 2) (Bagozzi, Yi 1988).

\section{Research results}

Structural model analysis (Fig. 1) yields good fit statistics $\left(\mathrm{X}^{2} / \mathrm{df}=1.9220\right.$; BBNNFI $=$ 0.923; CFI $=0.929$; GFI $=0.835$; SRMR $=0.057$; RMSEA $=0.042)$. Results (Table 5) provide support for different hypotheses ${ }^{1}$.

Emotional experience $\left(\mathrm{H} 1: \beta_{1}=0.093\right)$ directly and positively influences satisfaction. Both intellectual experience through design $\left(\mathrm{H} 2 \mathrm{~b}: \beta_{2 \mathrm{~b}}=0.346\right)$ and intellectual experience with employees $\left(\mathrm{H} 2 \mathrm{~b}: \beta_{2 b}=0.140\right)$ directly and positively influence emotional experience. Sensory experience $\left(\mathrm{H} 3 \mathrm{a}: \beta_{3 \mathrm{a}}=0.177\right)$ and pragmatic experience $\left(\mathrm{H} 3 \mathrm{~d}: \beta_{3 \mathrm{~d}}=\right.$ 0.269 ), directly and positively influence satisfaction. Sensory experience and social experience have no direct effect on emotional experience (have not been accepted H2a and

\footnotetext{
${ }^{1}$ For validation purposes, we compared proposed model (Fig. 1) with alternative models. The objective is to test whether, for sectorial context studied, the customer also experience emotions derived from pragmatic experience. Adding a direct influence of pragmatic experience on emotional experience don't yield evidence of significant effects.
} 
Table 5. Results of Structural Equation Model analyses

\begin{tabular}{|c|c|}
\hline \multirow{2}{*}{ Causal relationships } & Total sample $(\mathrm{N}=527)$ \\
\hline & $\beta(\mathrm{t}-$ Student $)$ \\
\hline H1: Emotional experience $\rightarrow$ Satisfaction & $0.093 *(1.537)$ \\
\hline H2a: Sensory experience $\rightarrow$ Emotional experience & ns \\
\hline H2b: Intellectual experience (design) $\rightarrow$ Emotional experience & $0.346 * * *(3.302)$ \\
\hline H2b: Intellectual experience (employees) $\rightarrow$ Emotional experience & $\mathbf{0 . 1 4 0 * * ( 2 . 3 1 9 )}$ \\
\hline H2c: Social experience $\rightarrow$ Emotional experience & $\mathrm{ns}$ \\
\hline H3a: Sensory experience $\rightarrow$ Satisfaction & $0.177 * *(2.542)$ \\
\hline H3b: Intellectual experience (design) $\rightarrow$ Satisfaction & ns \\
\hline H3b: Intellectual experience (employees) $\rightarrow$ Satisfaction & ns \\
\hline H3c: Social experience $\rightarrow$ Satisfaction & ns \\
\hline H3d: Pragmatic experience $\rightarrow$ Satisfaction & $0.269 * * *(3.531)$ \\
\hline H4: Emotional experience $\rightarrow$ Hedonic value & $\mathbf{0 . 5 5 9} * * *(6.683)$ \\
\hline H5: Pragmatic experience $\rightarrow$ Utilitarian value & $\mathbf{0 . 6 2 5 * * * ( 9 . 9 6 3 )}$ \\
\hline H6a: Hedonic value $\rightarrow$ Satisfaction & $0.341 * * *(4.573)$ \\
\hline H6b: Utilitarian value $\rightarrow$ Satisfaction & $\mathbf{0 . 3 2 5} * * *(5.443)$ \\
\hline \multicolumn{2}{|l|}{ Other significant relationships } \\
\hline Intellectual experience (employees) $\rightarrow$ Hedonic value & $0.166 * * *(3.518)$ \\
\hline Social experience $\rightarrow$ Hedonic value & $0.247 * * *(4.003)$ \\
\hline Overall fit of the structural model & $\begin{array}{c}\text { BBNNFI }=0.923 \\
\text { CFI }=0.929 \\
\text { RMSEA }=0.042\end{array}$ \\
\hline
\end{tabular}

Notes: $* \mathrm{p}<0,05 ; * * \mathrm{p}<0,01 ; * * * \mathrm{p}<0,001$

$\mathrm{H} 2 \mathrm{c}$ ). Although intellectual experience (through design and with employees) and social experience have no direct effect on satisfaction (have not been accepted $\mathrm{H} 3 \mathrm{~b}$ and $\mathrm{H} 3 \mathrm{c}$ ), indirect effects are observed, resulting from the mediating role of emotional experience and hedonic value. Emotional experience positively influences hedonic value (H4: $\beta_{4}=$ $0.559)$. Hedonic value is also positively and significantly influenced by intellectual experience with employees $(\beta=0.166)$ and social experience $(\beta=0.247)$. Favourable perceptions of pragmatic experience positively influence utilitarian value $\left(\mathrm{H} 5: \beta_{5}=0.625\right)$. Hedonic value $\left(\mathrm{H} 6 \mathrm{a}: \beta_{6 \mathrm{a}}=0.341\right)$ and utilitarian value $\left(\mathrm{H} 6 \mathrm{~b}: \beta_{6 \mathrm{~b}}=0.325\right)$ directly and positively influence satisfaction. In addition, hedonic value has a greater influence on satisfaction than utilitarian value.

Furthermore, the study provides consumer's perceptions for each experience dimension and sector analysed (Table 6). 
Table 6. Survey's main results

\begin{tabular}{lccccc}
\hline \multicolumn{5}{c}{ Consumer's experience } \\
\hline Sensory & $\begin{array}{c}\text { Intellectual } \\
\text { (design) }\end{array}$ & $\begin{array}{c}\text { Intelllectual } \\
(\text { employees })\end{array}$ & Social & Emotional & Pragmatic \\
\hline
\end{tabular}

\begin{tabular}{l|l|l|l|l}
\hline $\begin{array}{l}\text { Clothing stores } \\
\text { and fashion }\end{array}$ & & & & \\
\hline \hline Shoes & & & & \\
\hline \hline $\begin{array}{l}\text { Cosmetics } \\
\text { and perfumery }\end{array}$ & & & & \\
\hline \hline Jewelry & & & \\
\hline \hline Sports & & & & \\
\hline \hline Electronics & & & & \\
\hline \hline Decoration & & & \\
\hline \hline Bookstores & & & \\
\hline \hline Toys & & & \\
\hline
\end{tabular}

Note: Black boxes indicate above-average values for each type of experience

\section{Discussion}

Sensory, emotional and pragmatic experience are a significant predictors of satisfaction. The study findings are in line with Maklan and Klaus (2011), Srivastava and Kaul (2016) and Ali et al. (2016), who proposed that these types of experiences are important in the process of building customer satisfaction.

Our strongest and most innovative results concern the indirect impact of intellectual and social experience on satisfaction, through the mediating effect of emotions and shopping experience value. Moreover, our study relates shopping experiences with shopping experience value in line with Fiore and Kim (2007). Previous studies have also indicated that shopping experience value influence on customer satisfaction (Jones et al. 2006; Gholami et al. 2016). Our research also shows that hedonic value has greater influence on satisfaction than utilitarian value, although both components are needed to get a complete shopping experience.

\section{Conclusions}

This research is consistent with the fact that consumers want positive experiences in a retail store. The objective of this research was to explore consumer experience dimensions when they shop offline.

Consumer experience is manifested in several dimensions that can be grouped into two categories: emotional and pragmatic experience. Furthermore, the perception of intellectual experience (through design and with employees) can generate an emotional 
experience. As a result of these observations, our study has designed a scale to measure multidimensional experience.

In sport, decoration and toy sectors emotional and pragmatic experiences are present. Furthermore, emotional experience is mainly present in other sectors, like jewellery and bookstore, while pragmatic experience is shown in shoes, cosmetics and perfumery and electronics.

This research resolves a gap in our knowledge with a detailed analysis of relationships between experience dimensions, shopping experience value and satisfaction. Findings showed that pragmatic experience integrates decisions on product, price and promotion which affect the utilitarian value. The study also found that emotional experience has partial mediation effects (between intellectual experience - with employees - and the hedonic value) and total mediation effects (between intellectual experience - through design and with employees - and satisfaction and between intellectual experience through design - and hedonic value). Another conclusion is that hedonic value isn't only directly dependent on emotional experience, but also on social experience and intellectual experience with employees.

Emotional experience is mainly affected by intellectual experience (design and employees). This finding reinforces the idea that the consumer is a social being. In a retailer, stimuli that sales staff can create affect consumer emotions more than any other stimulus (sensory and social experience).

The research provides suggestions to support a retail manager. First, retailers must invest in utilitarian attributes of the product assortment, improving quality, while maintaining competitive price and promotions. Retailers should enhance the provision of quality in their product portfolio, with a mix of manufacturer brands and store brands. Manufacturer's brand can attract consumer to store, but private labels can turn customer into fans.

Second, it's very important to develop innovations related to experiences that generate emotions and hedonic value. The goal would be to invest in activities that help to stimulate consumer curiosity and imagination in store, causing positive emotions that favourably influence customer satisfaction and hedonic value. Augmented reality is an important new tool to help retailers to do this.

These emotions can be achieved by intensifying intellectual experience. For example, using an attractively designed store (furniture and decoration) to stimulate curiosity, and facilitate the testing of products. Furthermore, offering a complete experience through technology retail 3.0, with employees specially trained to offer a customised service and help customers to enjoy and be creative with new products or services. To generate hedonic value, it's possible to promote social shopping, a consumer experience that has an enjoyable time with their family and friends.

Finally, activating sensory experience complements the other experience dimensions, thereby helping to increase satisfaction. The retailer must invest in controlling lighting, hedonic touch (where touch is an end by itself), music and smells that provide a very pleasant shopping experience. 
This research has several limitations that could be addressed in future studies. First, it would be interesting to examine whether different dimensions of experience can predict specific results of attitudinal and behavioural loyalty. Second, although our research focuses on consumer experiences in offline retailers, the framework can be applied to online retailers. In an online context it can be difficult to get a sensory experience (e.g. tactile and taste experience). However, this experience can be replaced by other dimensions (e.g. flow state and connectedness with others in the virtual community).

\section{Acknowledgements}

The authors are grateful to Cátedra Fundación Ramón Areces de Distribución Comercial (http://catedrafundacionarecesdc.uniovi.es) for their valuable support to develop this empirical research.

\section{References}

Alba, J. W.; William, E. F. 2013. Pleasure principles: a review of research on hedonic consumption, Journal of Consumer Psychology 23(1): 2-18. https://doi.org/10.1016/j.jcps.2012.07.003

Ali, F.; Amin, M.; Cobanoglu, C. 2016. An integrated model of service experience, emotions, satisfaction, and price acceptance: an empirical analysis in the Chinese hospitality industry, Journal of Hospitality Marketing \& Management 25(4): 449-475.

https://doi.org/10.1080/19368623.2015.1019172

Arnold, M. J.; Reynolds, K. E. 2009. Affect and retail shopping behavior: understanding the role of mood regulation and regulatory focus, Journal of Retailing 85(3): 308-320.

https://doi.org/10.1016/j.jretai.2009.05.004

Arnold, M. J.; Reynolds, K. E. 2012. Approach and avoidance motivation: investigating hedonic consumption in a retail setting, Journal of Retailing 88(3): 399-411.

https://doi.org/10.1016/j.jretai.2011.12.004

Babin, B. J.; Darden, W. R.; Griffin, M. 1994. Work and/or fun: measuring hedonic and utilitarian shopping value, Journal of Consumer Research 20(4): 644-656. https://doi.org/10.1086/209376 Bagozzi, R. P.; Yi, Y. 1988. On the evaluation of structural equation models, Journal of the Academy of Marketing Science 16(1): 74-94. https://doi.org/10.1007/BF02723327

Bagozzi, R. P.; Gopinath, M.; Nyer, P. U. 1999. The role of emotions in marketing, Journal of the Academy of Marketing Science 27(2): 184-206. https://doi.org/10.1177/0092070399272005

Bhandari, S. 2016. Customer experience: an emerging source of sustainable competitive advantage, Imperial Journal of Interdisciplinary Research 2(7): 245-254.

Brakus, J. J.; Schmitt, B. H.; Zarantonello, L. 2009. Brand experience: what is it? How is it measured? Does it affect loyalty?, Journal of Marketing 73(3): 52-68.

https://doi.org/10.1509/jmkg.73.3.52

Ferguson, R.; Paulin, M.; Bergeron, J. 2010. Consumer sociability and the total service experience: antecedents of positive word-of-mouth intentions, Journal of Service Management 21(1): 25-44. https://doi.org/10.1108/09564231011025100

Fiore, A. M.; Kim, J. 2007. An integrative framework capturing experiential and utilitarian shopping experience, International Journal of Retail \& Distribution Management 35(6): 421-442. https://doi.org/10.1108/09590550710750313

Foroudi, P.; Jin, Z.; Suraksha, G.; Melewar, T. C.; Foroudi, M. 2016. The impact of innovation capability and customer experience on reputation and loyalty, Journal of Business Research 69(11): 4882-4889. https://doi.org/10.1016/j.jbusres.2016.04.047 
Gentile, C.; Spiller, N.; Noci, G. 2007. How to sustain the customer experience: an overview of experience components that co-create value with the customer, European Management Journal 25(5): 395-410. https://doi.org/10.1016/j.emj.2007.08.005

George, M. 2015. Haptics: the new wave of tactics for customer experience, International Journal of Informative \& Futuristic Research 2(8): 2606-2611.

Gholami, S.; Dehbini, N.; Shekari, A. 2016. The impact of store atmosphere on hedonic and utilitarian shopping values, customer satisfaction and customer purchase intention, Journal of Current Research in Science S(1): 305-311.

Hair, J. F.; Black, W. C.; Babin, B. J.; Anderson, R. E.; Tatham, R. L. 2006. Multivariate data analysis. $6^{\text {th }}$ ed. New York, NY: Prentice-Hall.

Hill, K. M.; Fombelle, P. W.; Sirianni, N. J. 2016. Shopping under the influence of curiosity: how retailers use mystery to drive purchase motivation, Journal of Business Research 69(3): 1028-1034. https://doi.org/10.1016/j.jbusres.2015.08.015

Hoegg, J.; Alba, J. W. 2007. Taste perception: more than meets the tongue, Journal of Consumer Research 33(4): 490-498. https://doi.org/10.1086/510222

Holbrook, M. B.; Hirschman, E. C. 1982. The experiential aspects of consumption: consumer fantasies, feelings, and fun, Journal of Consumer Research 9(2): 132-140.

https://doi.org/10.1086/208906

Hu, L. T.; Bentler, P. M. 1999. Cutoff criteria for fit indexes in covariance structure analysis: conventional criteria versus new alternatives, Structural Equation Modeling: a Multidisciplinary Journal 6(1): 1-55. https://doi.org/10.1080/10705519909540118

İpek, İ.; Aşkın, N.; İlter, B. 2016. Private label usage and store loyalty: the moderating impact of shopping value, Journal of Retailing and Consumer Services 31: 72-79.

https://doi.org/10.1016/j.jretconser.2016.03.011

Jackson, V.; Stoel, L.; Brantley, A. 2011. Mall attributes and shopping value: differences by gender and generational cohort, Journal of Retailing and Consumer Services 18(1): 1-9.

https://doi.org/10.1016/j.jretconser.2010.08.002

Javornik, A. 2016. Augmented reality: research agenda for studying the impact of its media characteristics on consumer behavior, Journal of Retailing and Consumer Services 30: 252-261. https://doi.org/10.1016/j.jretconser.2016.02.004

Jones, M. A.; Reynolds, K. E.; Arnold, M. J. 2006. Hedonic and utilitarian shopping value: investigating differential effects on retail outcomes, Journal of Business Research 59(9): 974-981. https://doi.org/10.1016/j.jbusres.2006.03.006

Kim, Y. K.; Lee, M. Y.; Park, S. H. 2014. Shopping value orientation: conceptualization and measurement, Journal of Business Research 67(1): 2884-2890.

https://doi.org/10.1016/j.jbusres.2012.06.006

Kim, Y. K.; Sullivan, P.; Forney, J. C. 2007. Experiential retailing: concepts and strategies that sell. New York, NY: Fairchild Publications.

Krishna, A. 2006. Interaction of senses: the effect of vision versus touch on the elongation bias, Journal of Consumer Research 32(4): 557-567. https://doi.org/10.1086/500486

Krishna, A. 2010. Sensory marketing: research on the sensuality of products. New York, NY: Taylor \& Francis Group.

Krishna, A. 2013. Customer sense: how the 5 senses influence buying behavior. New York, NY: Palgrave MacMillan. https://doi.org/10.1057/9781137346056

Krishna, A.; Morris, M. 2008. Does touch affect taste? The perceptual transfer of product container haptic cues, Journal of Consumer Research 34(6): 807-818. https://doi.org/10.1086/523286 
Labrecque, L.; Milne, G. 2011. Exciting red and competent blue: the importance of color in marketing, Journal of the Academy of Marketing Science 40(5): 711-727.

https://doi.org/10.1007/s11747-010-0245-y

Lang, J. T. 2015. Music and consumer experience, in D. T. Cook, J. M. Ryan. (Eds.). The Wiley Blackwell encyclopedia of consumption and consumer studies. West Sussex, United Kingdom: John Wiley \& Sons, Ltd., 435-437. https://doi.org/10.1002/9781118989463.wbeccs177

Lawton, S. 2016. Exploring the meal experience: customer perceptions of dark-dining, Chapter 9 in A. Jean-Vasile (Eds.). Food science, production, and engineering in contemporary economies. Hershey, PA: Information Science Reference, 225-244.

https://doi.org/10.4018/978-1-5225-0341-5.ch009

Maklan, S.; Klaus, Ph. 2011. Customer experience: are we measuring the right things, International Journal of Market Research 53(6): 771-92. https://doi.org/10.2501/IJMR-53-6-771-792

Mangleburg, T. F.; Doney, P. M.; Bristol, T. 2004. Shopping with friends and teen's susceptibility to peer influence, Journal of Retailing 80(2): 101-116. https://doi.org/10.1016/j.jretai.2004.04.005

Mathwick, C.; Malhotra, N.; Rigdon, E. 2001. Experiential value: conceptualization, measurement and application in the catalog and internet shopping environment, Journal of Retailing 77(1): 39-56. https://doi.org/10.1016/S0022-4359(00)00045-2

Mehrabian, A.; Russell, J. 1974. An approach to environmental psychology. Cambridge: MIT Press.

Möller, J.; Herm, S. 2013. Shaping retail brand personality perceptions by bodily experiences, Journal of Retailing 89(4): 438-446. https://doi.org/10.1016/j.jretai.2013.05.004

Morrin, M. 2010. Scent marketing: an overview, Chapter 6 in A. Krishna (Eds.). Sensory marketing: research on the sensuality of products. New York, NY: Taylor \& Francis Group, 75-86.

Nunnally, J. 1978. Psychometric methods. New York, NY: McGraw-Hill.

Oliver, R. L. 2010. Satisfaction: a behavioral perspective on the consumer. 2nd ed. New York, NY: M.E. Sharpe.

Peck, J. 2010. Does touch matter? Insights from haptic research in marketing, Chapter 2 in A. Krishna (Eds.). Sensory marketing: research on the sensuality of products. New York, NY: Taylor \& Francis Group, 17-31.

Raghubir, P. 2010. Visual perception: an overview, Chapter 14 in A. Krishna (Eds.). Sensory marketing: research on the sensuality of products. New York, NY: Taylor \& Francis Group, 201-207.

Rimkute, J.; Moraes, C.; Ferreira, C. 2016. The effects of scent on consumer behaviour, International Journal of Consumer Studies 40(1): 24-34. https://doi.org/10.1111/ijcs.12206

Sachdeva, I.; Goel, S. 2015. Role of store atmospherics on customer experience, International Journal of Multidisciplinary Approach \& Studies 2(3):72-83.

Scarpi, D.; Pizzi, G.; Visentin, M. 2014. Shopping for fun or shopping to buy: is it different online and offline?, Journal of Retailing and Consumer Services 21(3): 258-267.

https://doi.org/10.1016/j.jretconser.2014.02.007

Schmitt, B.; Brakus, J. J.; Zarantonello, L. 2015. From experiential psychology to consumer experience, Journal of Consumer Psychology 25(1): 166-171.

https://doi.org/10.1016/j.jcps.2014.09.001

Schmitt, B. H. 2003. Customer experience management. A revolutionary approach to connecting with your customer. New York, NY: John Wiley \& Sons.

Schmitt, B. H. 2010. Experience marketing: concepts, frameworks and consumer insights, Foundations and Trends in Marketing 5(2): 55-112. https://doi.org/10.1561/1700000027

Scholz, J.; Smith, A. N. 2016. Augmented reality: designing immersive experiences that maximize consumer engagement, Business Horizons 59(2): 149-161.

https://doi.org/10.1016/j.bushor.2015.10.003 
Smillie, L. D.; Wilt, J.; Kabbani, R.; Garratt, C.; Revelle, W. 2015. Quality of social experience explains the relation between extraversion and positive affect, Emotion 15(3): 339-349. https://doi.org/10.1037/emo0000047

Spinelli, S.; Masi, C.; Zoboli, G. P.; Prescott, J.; Monteleone, E. 2015. Emotional responses to branded and unbranded foods, Food Quality and Preference 42: 1-11.

https://doi.org/10.1016/j.foodqual.2014.12.009

Srivastava, M.; Kaul, D. 2016. Exploring the link between customer experience-loyalty-consumer spend, Journal of Retailing and Consumer Services 31: 277-286.

https://doi.org/10.1016/j.jretconser.2016.04.009

Thomson, M.; MacInnis, D. J.; Park, C. W. 2005. The ties that bind: measuring the strength of consumers' emotional attachments to brands, Journal of Consumer Psychology 15(1): 77-91. https://doi.org/10.1207/s15327663jcp1501_10

Verleye, K. 2015. The co-creation experience from the customer perspective: its measurement and determinants, Journal of Service Management 26(2): 321-342.

https://doi.org/10.1108/JOSM-09-2014-0254

Walsh, G.; Shiu, E.; Hassan, L. M.; Michaelidou, N.; Beatty, S. 2011. Emotions, store-environmental cues, store-choice criteria and marketing outcomes, Journal of Business Research 64(7): 737-744. https://doi.org/10.1016/j.jbusres.2010.07.008

Wang, C. L.; Ahmed, P. K. 2004. The development and validation of the organisational innovativeness construct using confirmatory factor analysis, European Journal of Innovation Management 7(4): 303-313. https://doi.org/10.1108/14601060410565056

Silvia CACHERO-MARTÍNEZ has a PhD in Marketing from School of Economics and Business from University of Oviedo (Spain). She is currently researcher in Cátedra Fundación Ramón Areces de Distribución Comercial. Her research focuses on cognitive and emotional influences to consumer decision making. Her current research interest focuses on customer experience, emotional branding, consumer behaviour, marketing management and customer service.

Rodolfo VÁZQUEZ-CASIELLES is currently Professor of Marketing at the University of Oviedo (Spain). His current research interests include retail management, distribution channels and services marketing. His recent articles have been published in the European Journal of Marketing, Industrial Marketing Management, International Journal of Research in Marketing, Journal of Service Management, Journal of Advertising Research, Journal of Business Research, Marketing Letters and Psychology and Marketing, among other journals. 